\title{
Jean Baudrillard ve Yeni Dünyanın İnşası: Göstergebilimsel Analiz Örneği
}

\section{- Aslıhan Dumlu}

Doktorant Süleyman Demirel Üniversitesi m.aslihandumlu@gmail.com ORCID ID: 0000-0003-00175815

\begin{abstract}
ÖZET
Postmodernizm, literatürde modernizmden sonra tartışmalı bir konu olarak yerini almıştır. Bu dönemde yapılmış pek çok çalışma içerisinde Jean Baudrillard'ın fikirleri dikkat çekmektedir. Baudrillard özellikle hipergerçek anlayışlyla postmodern döneme yeni bir kapı aralamıştır. Geliştirdiği simülasyon ve simülakr kavramları hipergerçek anlayışını pekiştirirken, gerçeğin değiştirilebilir yanina vurgu yapmaktadır. Dolayısıyla günümüz koşullarında gelişen teknolojiyle birlikte hipergerçeğin derinlik kazanmaya başlaması önemli görülmektedir. Çalı̧̧mada postmodernizm çerçevesinde Baudrillard'ın görüşlerine yer verilmiştir. Özellikle konu bağlamında açığa çıkarılmak istenen temel sorunsal, hipergerçeğin teknolojiyle birlikte daha karmaşık bir yapıya sahip olması olarak belirlenmiştir. Bu yüzden konunun işlerlik kazanması için Başlat: Ready Player One filmi amaçl örneklem olarak seçilmiştir. Örneklem olarak seçilmiş olan filme Roland Barthes'in fikirleri doğrultusunda göstergebilimsel analiz uygulanmıştır. Yapılan analiz sonucunda hipergerçeğin, teknoloji dünyastyla ilişkilendirilebilir çoklu sistem düzeninde giderek karmaşık bir yapıya sahip olduğu gözlemlenmiştir. Ayrıca gelişen sanal gerçeklik/VR teknolojisiyle hipergerçeğin de ötesinde yeni bir dünyanın izleri okunmuştur. Gerçek yerini hipergerçeğe bırakırken, hipergerçek yerini hipergerçek ötesi yeni bir boyuta bırakmaya başladığının yorumlanması yapılmıştır.
\end{abstract}

Anahtar Sözcükler: Modernizm, Postmodernizm, Hipergerçek, Teknoloji, Sanal Gerçeklik 


\section{Jean Baudrillard and the Construction of the New World: Semiotic Analysis Example}

\section{- Aslıhan Dumlu}

Doktorant Suleyman Demirel University

m.aslihandumlu@gmail.com ORCID ID: 0000-0003-00175815

\begin{abstract}
Postmodernism has taken its place in the literature as a controversial subject after modernism. Among many studies conducted in this period, Jean Baudrillard's ideas draw attention. Baudrillard opened a new door to the postmodern period, especially with his understanding of hyperreality. While the concepts of simulation and simulacrum he developed reinforce the hyperreal understanding, he emphasizes the changeable side of reality. Therefore, it seems important that hyperrealism starts to gain depth with the developing technology in today's conditions. The study included Baudrillard's views within the framework of postmodernism. Especially in the context of the subject, the main problematic that is wanted to be revealed was determined as hyperreality having a more complex structure with technology. For this reason, the movie "Start: Ready Player One" was chosen as the purposeful sampling. Semiotic analysis was applied to the film, which was selected as a sample, based on the ideas of Roland Barthes. As a result of the analysis, it has been observed that hyperreal has an increasingly complex structure in the multi-system layout that can be associated with the technology world. In addition, with the developing virtual reality technology, the traces of a new world beyond hyper reality have been read. The interpretation has been made that while real leaves its place to hyper reality, hyper reality has begun to take a way to a new dimension of beyond hyperreal.
\end{abstract}

Keywords: Modernism, Postmodernism, Hyperreality, Technology, Virtual Reality 


\section{GİRIŞ̧}

Günümüz toplumlarının postmodern döneme doğru geçiş yaşadığ1 görüşü literatürde s1klıkla tekrarlanmaktadır. Fakat postmodern dönem hakkında modern dönemin reddi mi, yoksa devamı mı, olduğu konusunda herhangi bir uzlaşı bulunmamaktadır.

Post eki ile geç anlamını çağrıştıran postmodernizmin kesin tanımlaması yapılamamaktadır. Temelde standartlara bağlılığı kıran, belirsizliği ve çoklu yapıları ön plana çıkaran postmodernizm farklı disiplinlerin bir arada bulunabildiği kavşak olmuştur. Dolayısıyla postmodernizmde yapılan çeşitli çalışmalar yeni kapılar aralamıştır. Postmodern izlekte karşımıza çıkan Jean Baudrillard'ın hipergerçek anlayışı yaşadığımız çağı algılamak açısından önemli sayılmaktadır. Bu alanda geliştirdiği simülasyon ve simülakr kavramlarıyla gerçeğin farklı formlarını ortaya koymayı amaçlayan Baudrillard, artık gerçeğin yansımalı bir şekilde bireylere ulaştığını belirtmektedir.

Baudrillard'ın söz konusu bu görüşleri teknolojinin geliştiği günümüz postmodern dünyasında giderek derinlik kazanmaktadır. Öyle ki gerçek hipergerçek olarak değiştirilmiş ve yansımalı şekilde bireylere ulaşırken, yapısı değiştirilmiş hipergerçeğin de tekrardan dönüştürülmesi ve yeni bir boyut kazandırılması aşamasına geçilmiştir. Bu durum çalışmada postmodern ve hipergerçek konu bağlamında amaçlı örneklem olarak seçilmiş Başlat: Ready Player One filmi ekseninde açıklanmaya çalışılmıştır. Yöntem olarak Roland Barthes'ın görüşleri doğrultusunda filme göstergebilimsel analiz uygulanmıştır. Özellikle kesit analizlerinde postmodern dünyanın betimlemesi ve hipergerçek boyutun değerlendirilmesi yapılmıştır.

Sonuç itibariyle Başlat: Ready Player One filminde sergilenen postmodern dünya ve hipergerçek boyut yorumlaması yaşadığımız dönemin doğru anlaşılmasına olanak sunmaktadır. Yapılan bu çalışmayla birlikte Baudrillard'ın fikirlerinin dayandığı postmodern dünya betimlenmiş, aynı zamanda örneklendirmeyle de hipergerçek anlayışa işlerlik kazandırılmıştır. 


\section{MODERNITE VE MODERNIZM}

Modern, yaşanılan döneme ithafen geliştirilen olguların ya da durumların mevcut konumlandırılışına işaret etmektedir. Türkçe sözlüğünde (TDK, tarih yok) yer alan tanımına göre de modern, çağa uygun olarak asrî ya da çağdaş anlamlarına denk gelmektedir.

Modern kelimesinden türetilen modernite sosyo-kültürel, ekonomik ve siyasal alanlarda meydana gelen değişimlerin toplamı olarak değerlendirilebilen olgulara işaret etmektedir. Bütün bu değişimler modernitenin; dinden felsefeye, ahlaktan hukuka, ekonomiden siyasete ve benzeri pek çok yapılardaki durumların eleştirisi bağlamında gelişmiştir. Bu eleştirilere karşılık Jeanniere (2011, s. 113) moderniteye geçişi sağlayan dinamik yapılardan bahsetmektedir. Bunlar; bilimsel, siyasal, kültürel, teknik ve endüstri alanındaki gelişmelerdir. Söz konusu gelişmelerden beslenen modernite özgürlük, sekülerizm ve yenilikler minvalinde var olmuştur.

Modernite tek bir bağlamda düşünülemeyeceği gibi tek bir zaman dilimi içerisinde de yer almamaktadır. Bu yüzden modernite Berman'ın (2006, s. 29) belirttiği gibi üç zaman dilimine ayrılmaktadır. Bunlar; 16. yüzyılın başlarından 18. yüzyılın başına kadar giden ilk zaman dilimi, 1790'da devrimlerin etkisiyle başlayan ikinci zaman dilimi, son zaman dilimi ise 20. yüzyılda modernitenin global etki kazanmasını kapsamaktadır. Geniş anlamlar dizesi içerisinde değerlendirilen modernite toplumsal düzeni değiştirmeye çalışmıştır. Eski olandan kopuşun her alanda başlamasıyla, eskinin sığ ve derin sularından yüzeye çıktığını zanneden modern insana çeşitli vaadler verilmiştir. Söz konusu vaadlerin arasında olan özgürleşme ise modernitenin ağır aksak ilerleyen gizil yapısı hâline gelmiştir.

Modernizm; rönesans, reform ve aydınlanma ile meydana gelen yeni dinamiklerden oluşan bir hareket olarak düşünülmektedir. Tam olarak ortaya çıkış tarihi konusunda tartışmalar olsa da çoğunlukla söz konusu dönemlerin ortak sonucunda oluştuğu kabul edilmektedir. Cevizci (2000, s. 603), modernizmin aydınlanmayla birlikte meydana gelen dünyevi, rasyonel ve ilerlemeci bir görüş, şeklinde düşünülmesi gerektiğinin altını çizmektedir. Dolayısıyla aydınlanma, modernizmin yorumlanması açısından önemli görülmektedir. Rönesans'tan reforma değişen toplumsal dinamikleri takiben aydınlanma çağının sahneye çıkması temelde aydınlanma felsefesi bağlamında gelişmiştir. Demir (2001, s. 27), aydınlanmayla birlikte ilâhiden beslenen 1şık teriminin 18. yüzyılda kaynağını akıldan, özgürlükten ve bireysel 
mutluluktan alan terim hâline geldiğini belirterek esas olan bilginin ve aklın 1şı̆̆ı olarak kabul edildiğine değinmiştir. Kilise'ye bağlı olan 1şık ise toplumda aydın kesim üzerinde etkisini yitirmeye başlamıştır. Aydınlanmayla kelimelerin ve kavramların anlamı değişerek yeni görünüm kazanmıştır.

Batı insanının düşünsel olarak kendisini revize etmesiyle aydınlanma felsefesi toplumlarda yayılma göstermiştir. Bu felsefenin yaşandığ 1 dönem ise "Aydınlanma Çağı" şeklinde tanımlanmıştır. Aydınlanma Çağı, İngiliz Devrimi ve Fransız Devrimi arasındaki dönem içerisinde yaşanan olayları anlatmak için kullanılmaktadır. Cevizci’ye (2002, s. 9) göre aydınlanma, kapitalizmin doğduğu ilk ülke olan İngiltere'de başlamış, Fransa'da güçlenmiş ve feodal düzenin yarattığı durumlardan dolayı en son Almanya'da hâkim olmuş ve 20. yüzyıl itibariyle pek çok ülkeye ulaşan akılcı ve entelektüel bir hareket olarak değerlendirilmektedir. Özellikle Fransız Devrimi sonucunda ortaya çıkan “eşitlik, adalet, özgürlük” gibi kavramların toplumlarda yayılmaya başlaması ve bireylerin farkındalık düzeyinin artması, batı insanının düşünsel temelli yeniden inşasını sağlamıştır. Aydınlanma döneminin önemli isimlerinden birisi olarak kabul edilen Immanuel Kant (2005, s. 225), “Aydınlanma Nedir?” yazısında Aydınlanma’yı tanımlarken kullandığı, “...Sapare Aude!”, “Aklını kullanma cesaretini göster!” sözü, şimdi aydınlanmanın parolası olmaktadır.” ifadeleri, Aydınlanma Çağı’nda bireysel dönüşümün iz düşümünü oluşturmaktadır. Söz konusu dönemle beraber aklını kullanma cesareti göstermeye başlayan birey, metafizik olanı eleştirel tutumla sorgulamaya başlamış, hak ve özgürlüklerin farkına varmıştır. Buna istinaden Karasar (2018, s. 5), aydınlanmada somut olgular üzerinde durulduğunu ve soyut olanın bilinmezliğinin tartışıldığını belirtmektedir. Aydınlanmacılar bu dönemde bir şey ya vardır ya da yoktur, ikisinin arası olan şey kabul edilemez fikriyle yola çıkarak aslında algılayamadığımız şeylerin olmadığını ileri sürmektedir.

Modern ile başlayan modernite ile süredigen ve modernizm ile taçlanan yeni dünyanın insanı ne modernin belirttiği eski olandan kopuşu keskin sınırlar içerisinde sağlayabilmiş, ne modernitenin savunduğu ilerlemecilik, özgürleşme ve benzeri yapıları tam anlamıla yakalayabilmiş ne de modernizmin vaadleri arasında olan aydın insanı topluma indirgeyebilmiştir. Özellikle sanayinin fordist yapıda sistematikleştirilmesi, bireylerin gündelik pratiklerine sirayet ederek kontrol altına alınmasını kolaylaştırmıştır. Kumar (2013, s. 68) fordizmi kapitalizmde yeni bir dönemi başlatan, üretimle beraber bireyi de kontrol altına alan, yeni işçi sınıfını oluşturmak için özel alan ve kamu alanını bulanıklaştıran bir yaklaşım olarak 
tanımlamaktadır. Bunun sonucunda birey pratiklerinde her alanda yerleştirilmeye çalışılan modernizm, modern görünümündeki toplumların oluşmasına katkı sağlamıştır. Bu konuda Jeanniere (2011, s. 112), modern dünyanın kendisinden daha önce var olmuş hiçbir yapı ile ilişkilendirilemez oluşuna vurgu yapmaktadır. Toplumsal dinamikleri ağ gibi saran modernizm hakkında özellikle ekonomik refomlarda kapital sürece hizmet etmesinden dolayı geçmişte eleştirdiği yapıların tekrarına düştüğü fikri oluşmuştur.

Modernizme yöneltilen eleştiriler genellikle sahip olduğu nitelikler bağlamında ilerletilmiş ve postmodernistler tarafından geliştirilmiştir. Yapılan eleştirilerin başında ilerlemeciliğe vurulan ket öne sürülmüş, postmodern doğrultusunda yeni dinamikler ortaya konmaya başlanmıştır.

\section{POSTMODERNITE VE POSTMODERNIZM}

Post eki ile sonra anlamına denk düşse de postmodern üzerinde varılmış kesin bir tanımlama bulunmamaktadır. Bu yüzden postmodernite hakkında modernitenin devamı mı, reddi mi olduğu konusunda uzlaşma sağlanamamıştır.

Postmoderniteyi yeni bir periyot olarak değerlendirenler moderniteye karşı eleştirilerini yönlendirenlerden oluşmaktadır. Örneğin Sarup (2010, s. 184), postmodernliğin modernitenin ortaya koyduğu toplumsal yapılardaki başarısızlıklara değindiğini belirtmektedir. Modernitenin savunucuları ise postmoderniteye karşı bir eleştiri geliştirmişlerdir. Bell (1976, s. 53), postmodernitenin narsizmi ortaya çıkarttığını ve geleneksel olana yapılan radikal bir saldırı olarak değerlendirmektedir. Verilen örnekler haricinde tartışmalı çalışmalara erişmek mümkündür. Fakat çalışmanın ana konusundan sapmamak adına bu tartışmalara burada yer verilememektedir.

Modernite akılcılığın, bilimin ve ilerilemeciliğin meşalesini vaad ederken, kuralları ve düzeni beraberinde getirmeye çalışmıştır. Postmodernite ise modernitenin vaadlerini yerine getiremeyişine karşı yeni bir soluk olarak değerlendirilmektedir. Batı'da yaşanan toplumsal hareketler sonucu modernitenin yetersiz kaldığı dönemde Tüzen'in (2008, s. 155) de belirttiği gibi kişilerin, toplulukların ve grupların sesini duyurmaya başlamasıyla birlikte sesin meşruluk olarak değerlendirilmesi, postmodern için çoğulculuğun doğma noktası kabul edilmektedir. Bu 
durum, modernitede yer alan tekliğin yerine çoğulculuğu ortaya çıkartmıştır. Böylece merkezi olan yapılar parçalanarak çoğalmış ve mekânların merkezisleşmesini peşi sıra getirmiştir.

Postmodernizm ise postmoderniteyle birlikte gelişen değerlerin, akım olarak devingenlik kazanmasına işaret etmektedir. Postmodernite gibi postmodernizmde de kesin bir tanımlama mevcut değildir. Bu durumun bir nedeni olarak, Huyssen'in çalışmasında ortaya koyduğu gibi postmodernizmin farklı tarihsel süreçlere ayrılmasından kaynaklandığını akıllara getirmektedir. Genel itibariyle, postmodernizmin ilk kez 1960 yılında Leslie Fiedler ve Ilhab Hassan gibi edebiyat eleştirmenlerince kullanıldığg bilinmektedir. Huyssen (2011, s. 233) postmodernizm teriminin; mimari, dans, tiyatro ve benzeri alanları kapsamına alarak sınırlarını genişletmesinin 1970'li y1lları bulduğunu belirtmektedir. Postmodernizm 60'l1 yıllarda kendi içerisinde farklı dinamiklerle değerlendirilirken, 70 ve 80 'li yıllarda küreselleşmeyle birlikte günümüzde kabul gören parçalanmışlığa ulaşmıştır. Kısacası postmodernizm, modernizmi eleştirerek onun kaynaklarından beslenen ve modernizmden farklı olduğu iddiasıyla yolan çıkan yeni bir döneme işaret etmektedir. Soykan’ a (1993, s. 118-122) göre postmodernizm muğlâklığı barındırmaktır. Modernizmdeki bütünlük yerine, postmodernizmde olan belirsizlikten dolayı parçalanmışılı ortaya çıkmaktadır. Postmodern dönemde gerçek olanın yerine onun kopyası tercih edilmektedir. Kopya ve gerçeği aynı içeriğe sahip olmaktadır. Özne olarak bireyin içi boşaltılmış ve otoritenin kabul görülmediği bilinmektedir. Geçmiş, gelecek ve şimdiki zaman ayırımında netlikten bahsedilememektedir. Postmodernizm, modernizmin aksine standart kalıpların yıkılmasını ve bireyselliği ön plana çıkartmaktadır. Postmodernizm, modernizmin benimsediği dinamiklerin haricinde; sosyo-kültürel, ekonomik, siyasal ve toplumsal pratik alanlarında yeni söylemler kazandırmanın başka bir yolu olarak görülmektedir. Örneğin; fordist sistemden, postfordist sisteme geçilmesi toplumsal değişikliklerin habercisi olmuştur. Saklı (2007, s. 114) postfordizmin, tüketim ihtiyaçlarını karşılayabilmek adına iş gücünde ve makineleşmede esnek üretimin desteklendiği, bilgi ve iletişim teknolojilerinin üretim aşamasında kullanıldığı hem üretim hem de birikim rejimi olarak değerlendirildiğini belirtmektedir. Fordizmdeki montaj hattı ve tek tip üretim yerine daha esnek kalıplara dayanan postfordist üretim, bireylerin günlük yaşam pratiklerini de etkilemiştir. Özellikle tüketimde postfordist yapının işlerlik kazanması, kapitalizmin kendisini revize etmesini sağlamıştır. 
Modernizmdeki pratiklerin yerine postmodernizmdeki pratikler kaotik bir toplumsallaşmayı beraberinde getirmiştir. Dolayısıyla kuralsızlığı kural olarak kabul eden postmodernizme duyulan inanç, modernizmde hissedilen umutsuzluğu hatırlatmaktadır.

\section{POSTMODERNIZM, JEAN BAUDRILLARD-HIPERGERÇEK}

Postmodern çalışmalar içerisinde fikirleriyle literatüre yeni bir kapı aralayan Jean Baudrillard'ın pek çok dile çevrilmiş eserleri bulunmaktadır. Çalışma ekseninde postmodern minvalinde Baudrillard'ın hipergerçek anlayışı ön plana çıkarılacaktır.

Günümüz sorunsallarının, modern kavramlarla ve paradigmalarıyla açılanamayacak düzeye gelmesiyle birlikte ortaya çıkan postmodern, Baudrillard'ın (2011, s. 14) görüşlerinde gerçekliğin anlamını yitirmesine dayanmaktadır. Bu zamanda gerçek asla yerine gelmeyecek olandır. Gerçek, kendisi yerine geçen göstergelerin gerçeğidir. Böylece postmodernizm anlamsız ve değişken yığınları kendisine mesken tutmaktadır. Postmodernizmde zamanın önemi kalmamıştır. Uryy (1999, s. 292-293) postmodern kültürü; modern dönemdeki durağan kimliklerin yerine geçen akışkan kimliklerle sarmalanmış, geleceğin ve şimdinin aynı konumda olabildiği "bir anlık" zaman ideası üzerine oturtulmuş kültür olduğunu vurgulamaktadır. Postmodern kültür diliminde "şu an" neler olup bittiği önemli kılınmaktadır. Bu durumun sonucunda postmodernizmdeki süreksizlik gerçeğe farklı kılıflar giydirebildiği gibi zamanı da gizleyerek anlaşılmasını zorlaştırmaktadır. Bunlara ilâveten, modernizmden postmodernizme geçişte insanın postmodern bulanıklığı içerisinde özgürleştiğini savunan Baudrillard, günümüzde gerçekliğin de boyut atladığını vurgulamaktadır.

Baudrillard simulakr ve simülasyon kavramlarıyla "gerçek" olanın ne olduğu konusunda fikirler öne sürmüştür. Simulakr (2011, s. 12), gerçeklik olarak algılanan olgulara işaret etmektedir. Simülasyon ise (2011, s. 13-14) maketlerle ya da bilgisayar programlarıyla birlikte gerçekliğin yeniden üretilmesine dayanmaktadır. Simülasyon ya da hipergerçek olarak adlandırılan gerçeğin farklı biçimde yansıtılması, postmodern dönemin gerçeğinin algılanması açısından önem taşımaktadır. Baudrillard günümüzdeki gerçeğin matrisler, bellekler ya da minyatür hale getirilmiş hücreler tarafından üretildiğini belirtmektedir. Bunların sonucunda Best ve Kellner'ın da belirttiği gibi Baudrillard'a (2016, s. 173) göre hipergerçek tüm bu modellerin yerini almaktadır. Söz konusu hiperçek; dergilerdeki, televizyon programlarındaki, 
reklamlardaki, modadaki ve benzeri dinamiklerde gösterilen ideal kadın, ideal erkek, ideal seks, ideal moda örüntüleri gibi olgularda hayat bulmaktadır. Gerçeğin farklı şekillerde yansitılması bireyin gündelik pratiklerinde dahi gerçek ile hipergerçek arasındaki ayrımın yok olmasına neden olmaktadır. Hipergerçek ilerledikçe de simülasyonlar gerçekliğin farklı revizeleriyle karşımıza çıkmaktadır. Gerçek yerini hipergerçeğe bırakırken, hipergerçek ise daha grift bir yapıya ulaşmaktadır. Bu durum Güzel' e göre (2014, s. 61) çoğulcu sanal gerçekleri oluşturmakta ve tek bir gerçeklikten söz etmeyi engellemektedir. Yapay ortamlarda üretilen hipergerçekle gerçeğin sayısız revizesi sunulmaktadır.

Postmodern dönemde gerçekliğin yok olmasıyla toplumsal yapılardaki değişimlere toplumsalın sonu fikriyle dikkat çeken Baudrillard (2010, s. 29) içe göçme kavramını kullanmaya başlamıştır. Postmodern toplumda içe göçme; anlamın medyada, medyanın da toplumsal olanda içe göçmesi anlamına gelmektedir. Böylece kitleler mesajların ve imajların yağmalamasına tutularak, kanaat denetlemesi yapılmaktadır. Cevizci (2009, s. 751), içe göçüşle beraber toplum ve kültür sınırlarının ve bunlara ait olan farklılıklarının yok olarak birbirinin içine geçtiklerini belirtmektedir. Böylece toplumsalda yeni dinamiklere bağlı oluşturulan yeni gerçekler açığa çıkmaktadır. Oluşturulan yeni gerçeklikle siyaset, ekonomi, aşk, cinsiyet, cinsellik ve benzeri dinamiklerde de postmodern bulanıklaşma görülmektedir. Sınırların farkına varamayan postmodern bireyler; iyi-kötü, doğru-yanlış ve hayal-gerçek arasındaki dengeyi kuramamaya başlamaktadır.

Sonuç olarak Baudrillard'ın sıklıkla üzerinde durduğu, modernizmi eleştirdiği noktalardan birisi olan özgürleşme, postmodern dönemde hipergeçekliğin sağladığı yansımalı gerçekliklerle muğlâk olarak bireylere sunulmaktadır. Bu dönemde birey kendisini özgür zannederken aslında teknolojinin farklı bir uzantısı olarak kendi varlığını farklı bir şekilde yeniden üretim ağına dâhil etmektedir. Gerçek ve hipergerçek arasındaki ilişkinin bütünleşmesi sonucu birey kendisini özgür zannederken, McLuhan ve Postman'ın tartışmalarına konu olan teknolojinin uzantısı olarak, öz gerçekliğini yitirmektedir. Postmodern dönemde gerçeklik birden fazla kıyafet giymeye başlamıştır. Anlık olana işaret eden söz konusu dönemin gerçeği de anın getirdikleri ya da götürdükleri bağlamında kostüm değişikliği yapmaktadır. 


\section{HIPPERGRÇEK VE SANAL GERÇEKLIIK-VR (VIRTUAL REALITY) TEKNOLOJISI}

Teknolojinin giderek yol katettiği günümüz dünyasında insanoğlunun yaptığı pek çok işi artık teknik donanıma sahip aletler yapmaktadır. Modern dünyada görülen fabrika işlerinin seri üretim bandıyla kolaylaşmasından, postmodern dünyada görülen parçalı ve farklı ürün üretimlerine değin teknolojinin getirileriyle karşılaşmaktayız. Geniş bir tarihsel arka planı ve bağlamı olan teknolojinin konu bağlamındaki hipergerçek üzerinden sanal gerçeklik/VR teknoloji uygulaması üzerinde durulacaktır.

Sanal, kelime anlamı olarak Türkçe sözlüğünde (TDK, tarih yok) belirtildiği gibi gerçek olanda bulunmayan, zihinde tasarruf edilen anlamına gelmektedir. Geniş anlamsal yüzeye sahip olan sanal kavramı bir yanıyla zihinsel fonksiyonlara işaret ederken, diğer yanıyla gerçekliğin farklı şekillerde vuku bulması olarak değerlendirilmektedir. Gerçeğin hipergerçek olarak simülasyonlarda yeniden yaratılması, sanal gerçeklik/VR teknolojisinin gelişmesiyle mümkün olmuştur. Mutlu (2012, s. 263), sanal gerçekliği bigisayar ya da farklı iletişim araçlarıyla var edilen ve kullanıcının kendisini içerideymiş gibi hissettiği mekân olarak yorumlamaktadır. Daşkıran (2016, s. 68) ise sanal gerçekliği gözümüzün önüne yerleştirilen ekranlar aracılığıyla dış/gerçek dünyadan kopmamız ve sanal dünyanın merkezinde konumlanmamız olarak açıklamaktadır. 1980'lerin başında denenmeye başlanan VR teknolojisi, tüketiciye ancak 2016 yılı itibariyle ulaşmıştır. VR teknolojisinin kullanıma hazır olmasının uzun dönemden sonra gerçekleşmesinin en önemli etkeni teknolojideki gelişimleri takip etmesine dayanmaktadır. Çünkü VR teknolojisinde kullanılan aletler genellikle gözün üzerine yerleştirilen ekran, bilgi işlem aygıtı ve kontrol cihazından oluşmaktadır. Farklı parçaların bir araya getirildiği söz konusu teknolojinin kullanıma hazır hale gelmesinde ister istemez teknik ve teknolojik ilerlemenin beklenilmesi gerekilmiştir.

VR teknolojisiyle yeni dünyalar, yeni görünümler ve benzeri olguları yaratmak kolaylaşmaktadır. Hoffman (1995, s. 48), sanal dünyada karşılaştığımız yaşam görüngülerinin katılımcının eylemlerine yönelik meydana geldiğini ve gerçekçiy-miş gibi algılanan bu geri dönütlerle katılımcıların sanal evrende bir yerlerdey-miş gibi hissetmelerine yol açtığına değinmektedir. Yaratılan sanal dünyanın içerisinde yer almak isteyen birey, gerçek dünyadan sıyrılmaktadır. Berryman (2012, s. 213) VR'da her şeyin dijital veya gerçekliğin bir 
simülasyonu olduğundan bahsetmektedir. VR teknolojisinin sahip olduğu aletler ile sanal dünyaya bağlanan bireyler, -mış gibi hissini gerçekliğin yerine koymaktadır. Yaratılan sanal dünya gerçek olanların önüne geçmektedir. Bireyin algı mekanizmasındaki bu ilişiksizlik gündelik pratiklerde giderek yarık açmaktadır. Dolayısıyla Baudrillard'ın postmodern çalışmalarında ön plana çıkarttığı hipergerçek anlayışı VR teknolojisinin gelişmesiyle giderek dinamiklik kazanmakta ve kendi içerisinde farklı katmanlara, tahmin edilemeyecek hiper boyutlara sahip olmaktadır. VR teknolojisi beraberinde bedensizleşme, ölümsüzlük, zaman ve mekânda parçalanmışlık fenomenlerini bireylere sunmaktadır.

Meijsing (2006, s. 445-446) sanal dünyadaki bedensizleşmeyi hayalet uzuv fenomeniyle açıklamaktadır. Bu açıklamaya göre sanal bedenlerin, gerçek dünyada var olan biçimi akıllara gelmektedir. Beyinsel fonksiyonlar için söz konusu durum, vücutta bulunma açısından fiziki beden ihtiyacının olmayışının işareti kabul edilmektedir. VR teknolojisi sayesinde bireyler, somut bir bedene gerek duymadan sanki o bedene sahip-miş hissini yaşayarak sanal dünyanın gizemi içerisinde kaybolmaktadır. Yine aynı şekilde ölümsüzlüğün sanal dünyada vuku bulmadığı gibi zaman ve mekândaki parçalanmışlık VR teknolojisinin çok katmanlı yapısına örnek teşkil etmektedir.

VR teknolojisinin kullanılmaya başlandığ 1 alanlar arasında en yaygın olarak dijital oyunlar örnek verilebilir. Film konularında da VR teknolojisinin aktif kullanılması, yorumlanması gereken başka bir değerlendirme sürecine 1şık tutmaktadır. Bu yüzden konu bağlamında amaçlı örneklem olarak seçilmiş olan Başlat: Ready Player One filmi hipergerçeğin değerlendirilmesi ve kuramsal zemininin örneklendirme yoluyla derinlik kazandırılması için önemli görülmüştür.

\section{YÖNTEM}

Çalışmanın bu bölümünde, postmodernizmin ve Baudrillard'ın değindiği hipergerçeğin gelişen teknolojiyle birlikte çoklu katmanlara sahip olabilmesinin örneklendirilmesi yapılmıştır. Söz konusu örnekleme; konu minvalinde amaçlı seçimi yapılan ve bir yanıyla gerçek ile sanal dünya ayırımındaki bireyleri sorgulatırken diğer yanıyla da postmodern izler çizen 2018 yapımı Başlat: Ready Player One filminde gerçekleştirilmiştir. Seçilen filmde 
üzerinde durulan olguların geniş kapsamlı incelenebilmesi için Roland Barthes'ın görüşleri bağlamında göstergebilimsel analiz uygulanmıştır.

Turner (2016, s. 27), göstergebilimin temsillerin kültürel niteliklerini ve ne anlama geldiklerini açıklayabilmek için aynı yöntem, kavram ve terimleri kullanmamıza olanak verdiğini söylemektedir. Göstergebilimsel analiz temelinde gösteren ve gösterilen yapıların düz ve yan anlamlarının tanımlanması için kullanılmaktadır. Bu bağlamda Barthes göstergebilimde, dilbilimi esas alarak dil-söz, gösteren-gösterilen, dizge-dizin, yan anlam-düz anlam yapılarıyla yeni bilim anlayışına özgü olabilecek yeni yöntemleri incelemiştir. Ayrıca değindiği kavramların ele alınan konuya göre farklı şekillerde yorumlanabileceğini de belirtmektedir. Barthes (1979, s. 22), geliştirdiği kavramlar içerisinde yan anlama özellikle önem vermiştir. Gösteren fiziki formdaki görülen ya da duyulana işaret ederken, gösterilen ise gösterenin zihindeki yansımasıdır. Düz anlam, herhangi bir şeyin akla ilk gelen anlamını belirtirken yan anlam iletişim çalışmalarında daha ideolojik örüntülerle gizlenmiş anlamları bünyesinde barındırmaktadır. Tüm bunların yanı sıra Barthes, metafor ve metanomi ile anlamlandırma boyutlarına derinlik kazandırmayı amaçlamıştır.

Göstergebilim kıstasında değerlendirilen filmde tablo analizinin yanı sıra kesit analizi de yapılmıştır. Kesit analizinin yapılabilmesi için film içerisinden örnekler alınmıştır. Söz konusu bu örneklerin seçilmesinde ise Baudrillard'ın (2011, s.14) postmodern dönemde gerçekliğin hipergerçek olarak minyatürleştirilmiş hücreler, matrisler, bellekler ve komut modelleri tarafindan üretildiğine yönelik düşünceleri etkili olmuştur. Baudrillard'ın gerçeğin, hipergerçek olarak nasıl ve ne şekilde üretildiğine dayanan görüşleri filmde söz konusu duruma uygun düşen kesitler aracılığı ile örneklendirilmiştir. Ayrıca bu duruma ek olarak gelişen teknik ve teknolojik sıçramalar da var olan sanal gerçeklik (VR) teknolosiyle birlikte postmodern dünyada zaman ve mekân olgusunda yaşanan kopmalarla neticelenmiştir. Postmodern dünyanın beraberinde getirdiği küresel sınırsızlık bireyin farklı kimliklere ait olma şansını da arttırmıştır.

Harvey'in (2010, s. 305) de belirttiği gibi postmodern dönemde zaman mekânsallaşmaya, mekân da zamansallaşmaya başlamıştır. Zamanda ve mekânda yaşanan özgürleşme, postmodern dönemi daha kaotik, düzensiz ve süreksiz yapısına kavuştururken aynı zamanda çeşitli alt kimliklerin sahneye çıkmasını da kolaylaştırmaktadır. Kumar (2013, s. 148), postmodern dönemdeki çoğulcu kimliklere vurgu yaparak, modern dönemdeki kolektif 
kimliklerin yerini daha özelleşen kimliklerin aldığından bahsetmektedir. Farklı olanın değerinin arttığı bu dönemde kimlikler, yaşadığ 1 değişimle üniter olmaktan çıkmaktadır. Postmodern bireyin sahip olduğu çoklu kimlik olgusu, teknolojinin sağladığı zaman ve mekândaki özgürleşme ve bunlara bağlı olarak da Baudrillard'ın ortaya koyduğu gibi gerçeğin teknolojiyle kolay bir şekilde hipergerçeğe dönüştürülmesi, postmodern bireyin kimliklerine yeni imajları dâhil etmesini kolaylaştırmaktadır. Bu dönemde birey daha güzel, daha zayıf, daha akıllı ve benzeri imajları teknolojinin getirileriyle birlikte kimliklerine hipergerçek boyutta eklemleyerek merkezsiz özneliğini yaşamaktadır. Söz konusu kuramsal temellendirmeden hareketle film içerisinden seçimi yapılan kesitlerin postmodern dünya ve hipergerçeklik fikirlerine dair somut göstergeler teşkil etmesi hedeflenmiştir.

\subsection{Filmin Konusu}

Dünya, 2045 yılına gelindiği zaman yaşanılacak bir yer konumundan çıkmıştır. Bu yüzden insanların hepsi günlük vakitlerini OASIS adı verilen sanal evrenin içerisinde geçirmektedir.

OASIS'ın kurucusu James Halliday, kısa bir süre sonra hayata gözlerini yumacağı için yarattığı sanal dünyada herkesin yarışıp bulması gereken 3 anahtar saklamıştır. Bu anahtarlar oyuncular1 oyunun en sonunda bulunması gereken yumurtaya götürmektedir. Oyunun nası1 gelişeceği ve sonunda ne olacağ1 Halliday'in ölümünden önce çekilmiş olan ve kendisinin anlattığı video ile açıklanmıştır. Buna göre yumurtaya sahip olan kişi oyunun bitmesini sağlayacak, aynı zamanda da 500 milyar dolara ve OASIS dünyasının tam kontrolüne sahip olacaktır. Herkesin kıran kırana yarışmaya ve anahtarları bulmaya çalışması ise videonun oyuncular tarafindan izlenmesiyle başlamıştır. Colombus, Ohio'da yaşayan Wade Watts ve onun sanal arkadaşları da bu yarışa dâhil olur ve filmin seyri gelişmeye başlar.

\section{ANALIZ VE BULGULAR}

Çalışmanın bu bölümünde konu minvalinde amaçlı olarak seçilmiş Başlat: Ready Player One filmine göstergebilimsel analiz uygulanmıştır. Filmin analizi, Barthes’ın görüşleri perspektifinde ele alınmış ve değerlendirmelerde bulunulmuştur. 


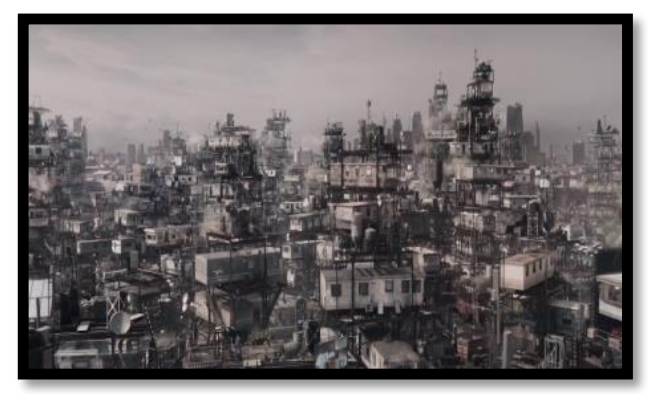

Kesit 1

Kesit 1, filmin ilk sahneleri arasında yer almaktadır. Postmodern dönemdeki gerçek dünya genel çekim ile kadrajda gösterilmiştir. Bu karede temel rengin gri olması yaşanılan dönemin kasvetliğini gözler önüne sermektedir. Kare yaklaştıkça ise insanların üst üste yerleştirilmiş eski banliyö tarzı evlerde yaşamasının görülmesi postmodernin izleri olan toplumdaki karmaşıklığg, kaosu ve düzensizliği nitelemektedir. Kesit 1, Gasset'in (2010, s. 40) modern dünya için söylediği tıklım tıklım kalabalıkların kentleri, evleri ve benzeri yerleri doldurmasına dair eleştirilerini akıllara getirmektedir. Aynı zamanda postmodernin modernden ayrı bir dünya yaratmadığı sadece farklı revizelerle yeniden yorumlandığı kabulünden hareketle Eagleton'un (1999, s. 9) postmodernizmi modern dönemin sebep olduğu gerilimden doğan ve büyüyen oidipal bir çocuğa benzettiği yorumuna istinaden Gasset'in değindiği tıklım tıklım kalabalıklarla dolu olan modern toplumun, postmodern dönemde daha da kalabalıklaşarak, şehirde nefes alacak, yaşayacak ve benzeri alanların artık hiç kalmadığı değerlendirilmesi yapılabilmektedir. Kesit 1 de söz konusu değerlendirmeden doğan postmodern toplumun kalabalıklığını göstermektedir. Ayrıca Kesit 1'de yığınlar olarak adlandırılan bu yeri/dönemi filmin başkahramanı Wade Watts, insanların sorunları çözmek yerine sorunlarla yaşamaya başladığı, güzel olmayan bir yer olarak nitelendirmektedir. Postmodern dönemin kalabalıklaşan kaotik dünyasında, sorunların çözümsüz kalmasına değinerek postmodern özellikleri içerisinde barındıran bu sahneleme, postmodern dünyayı yorumlamak açısından önemli sayılabilir. 


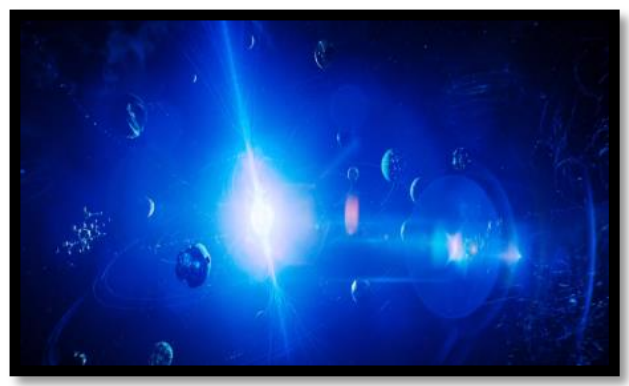

Kesit 2

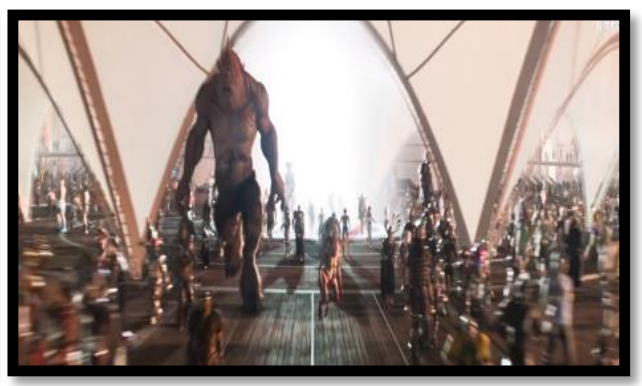

Kesit 3

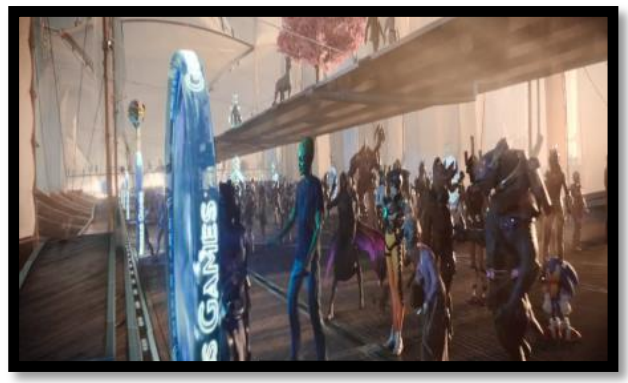

Kesit 4

Kesit 2, Kesit 3 ve Kesit 4 ise sanal evreni/OASIS'i göstermektedir. Film içerisinde farklı görünümlerde, farklı yerlerde ve farklı şekillerde var olan sanal evren söz konusu karelerde görülmektedir. Ayrıca Kesit 3 ve Kesit 4 de simülasyona bağlanan kişilerin sanal dünyadaki "kimlik"leri yani avatarları da sahnelenmiştir. Sanal evrenin/OASIS' in gösterildiği söz konusu karelerde Wade Watts'1n sözleri dikkat çekmektedir. “OASIS, gerçekliğin hayal gücümüzle sınırlı kaldığı bir yer... burada istediğimizi yapabiliriz, istediğimiz yere gidebiliriz... İnsanlar OASIS'e yapabilecekleri şeyler için gelir (yemek, uyku ve tuvalet haricinde), Fakat olabilecekleri onca şey için kalırlar. Uzun, güzel, korkutucu farklı cinsiyet, faklı tür... Ne istersek." Watts'ın bu sözleri, bireylerin simülasyona neden bağlanmak istediklerinin kısa özetini oluşturmasının yanı sıra bireylerin sahip olduğu kimliklerin çoğulculuğuna ve kimliklerarası geçişin kolay hâle gelmesine vurgu yapmaktadır. Bu durum postmodernizmdeki çoğulcu kimlik ve akışkan kimlik gibi olguların örneklendirilmesinde önemli görülmektedir. 


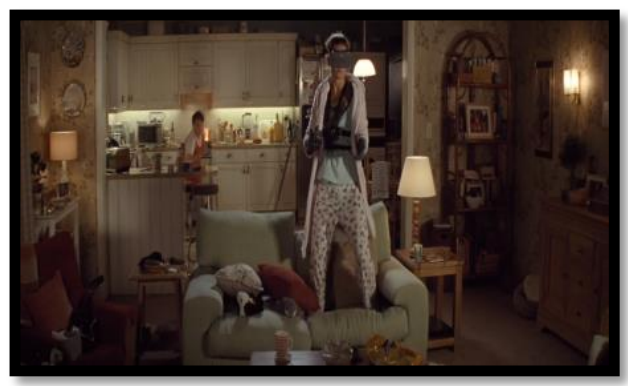

Kesit 5

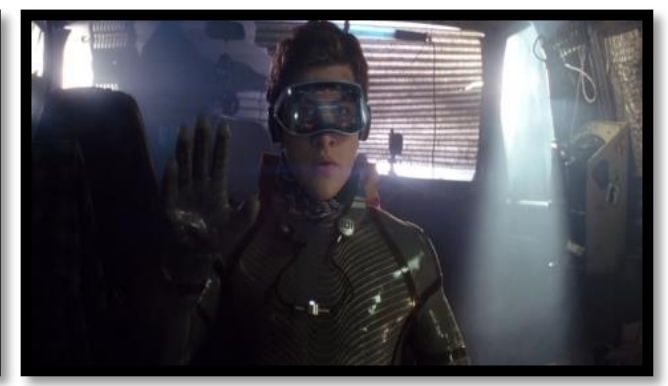

Kesit 6

Kesit 5 ve Kesit 6'da gerçek dünyadaki kişilerin simülasyona teknolojik aletler aracılığıyla bağlanması gösterilmiştir. Simülasyona bağlanma aracı olan aletler, filmde iki ayrı şekilde gruplandırılmıştır. Bunlardan birincisi; dokunsal kostüm, ikincisi ise eldiven ve vizördür. Kesit 5'te yer alan karede koltuğun üzerindeki kadın karakteri, eldiven ve vizör kullanarak simülasyona katılırken, Kesit 6'daki filmin başkahramanı Wade Watts'ın, oyundaki birinci anahtarı bulmasından sonra kavuşstuğu dokunsal kostüm ile simülasyona bağlandığını görmekteyiz. Kısacası film içerisinde yer alan teknolojik sıçramalarla birlikte VR teknolojisinin kullanımında değișen ve kullanıcıların daha etkin hislere sahip olmasını sağlayan kostümsel farklar dikkat çekmektedir.

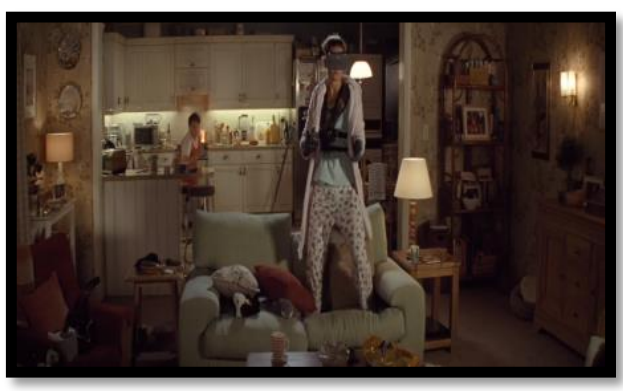

Kesit 7

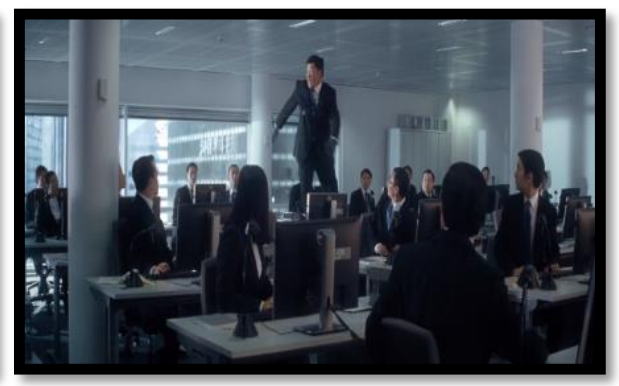

Kesit 8

Kesit 7 ve Kesit 8' de simülasyona bağlanan kişilerin gerçek hayattaki bireysel rollerinin farkındalığını yitirmesine örnek teşkil etmektedir. Bu bağlamda bir önceki kare analizinde de ele alınan Kesit 7, burada farklı şekilde değerlendirilmiştir. Koltuğun üzerinde eldiven ve vizörle simülasyona bağlanmış kadın karakterin, hemen arkasındaki erkek çocuğunun tüm seslenmelerine rağmen onu duymaması, ocaktaki yangını fark etmemesi, kadının gerçek dünyadan bağını kopardığının göstergesidir. Kesit 8 'de ise iş yerinde simülayona bağlanmış ve kazandıklarını kaybeden erkek karakterin masaların üzerinden koşarak daha sonra pencereye yönelip intihar etmek istemesi gösterilmiştir. Kesit 7 ve Kesit 8'de sahnelenen olaylar, tam da 
Badurillard'ın bahsettiği postmodern insanının sanal ile gerçek arasındaki ayrımı yavaş yavaş kaybettiği yönündeki görüşlerini destekler yöndedir.

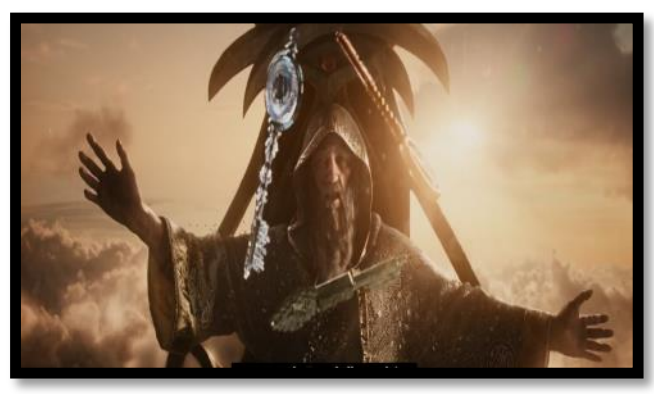

Kesit 9

Kesit 9'da OASIS'in kurucusu James Halliday'in avatar1 Anorak görülmektedir. Oyun içerisinde bulunmasını istediği anahtarlar hakkında konuşan Anorak, anahtarlara arzu nesnesine ulaşmak için araç misyonu yüklerken, oyunun sonunda bulunması gereken yumurtayı arzu nesnesi konumuna getirmiştir.

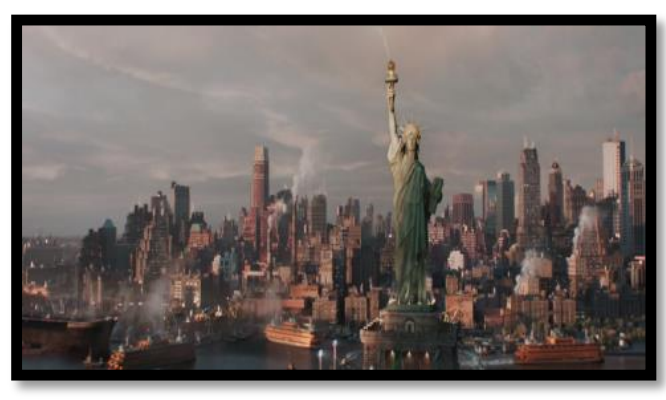

Kesit 10

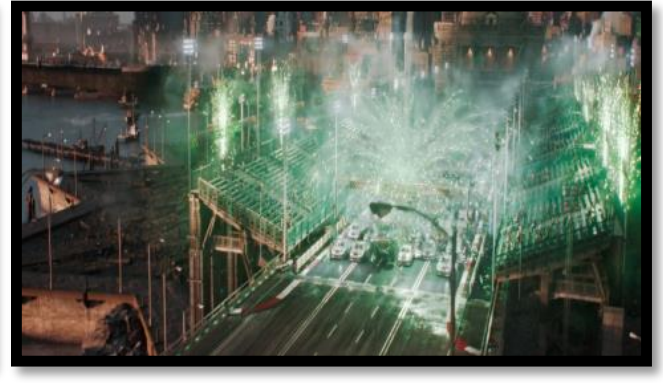

Kesit 11

Kesit 10 ve Kesit 11 sanal evren/OASIS oyun yolunun inşasını göstermektedir. İlk anahtarın bulunması için oluşturulan yarış parkuru köprüsü Özgürlük Anıtı'ndan atılan işaret fișeği ile başlamaktadır. Kesit 11'de New York şehrini kopya edilerek gerçekliğin farklı şekildeki simülasyonu yaratılmıştır. Özgürlük Anıtı'nın gösterilmesi yan anlamda hipergerçek arenada bireyin özgürleşmesine işaret etmektedir, şeklinde yorumlanabilir. 


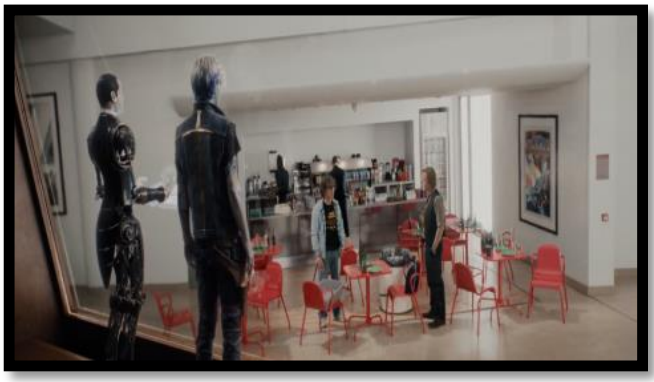

Kesit 12

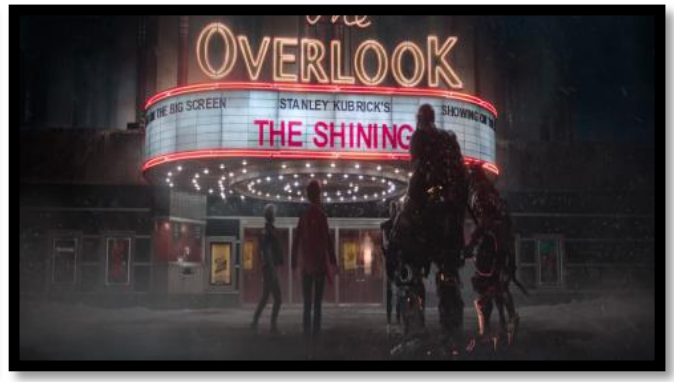

Kesit 13

Kesit 12 postmodern dünyadaki zamansızlığa örnek olarak verilebilir. Kesit 12 'de OASIS'te Wade Watts'ın avatarı Parzival, gerçek dünyadaki oyunun kurucusu James Halliday'in arkadaşı ile yaptığı görüşmeyi o andaymış gibi izlemektedir. Ayrıca gerçekliğin sanal evrende eğilip bükülebilmesini de ele alan Kesit 12'de Parzival, gerçek dünyadaki Halliday'in anına yaklaşarak ya da uzaklaşarak şahit olmaktadır. Yine aynı şekilde zamanın içinde zamanın yaşanması oyunun içinde oyun kurulması ve yeni gerçekliklerin inşa edilmesi Kesit 13'te sahnelenmiştir. Parzival ve arkadaşları yakaladıkları ipucunun peşinden gittiği söz konusu karede kendilerini The Shining filminin içerisinde bulmaktadır. Stanley Kubrick'in 1980 yapımı The Shining filmi, film zamanına indirgenerek zaman ve uzamın parçalanması örneklendirilmiştir.

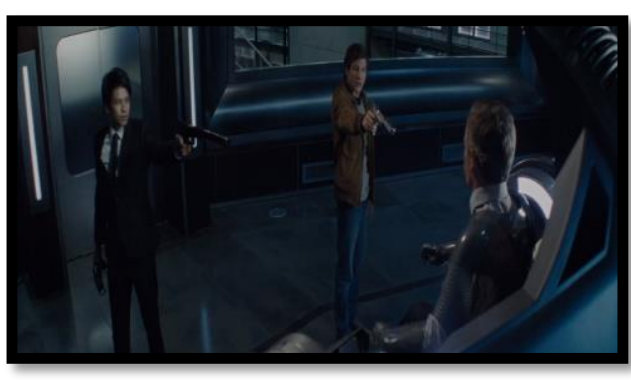

Kesit 14

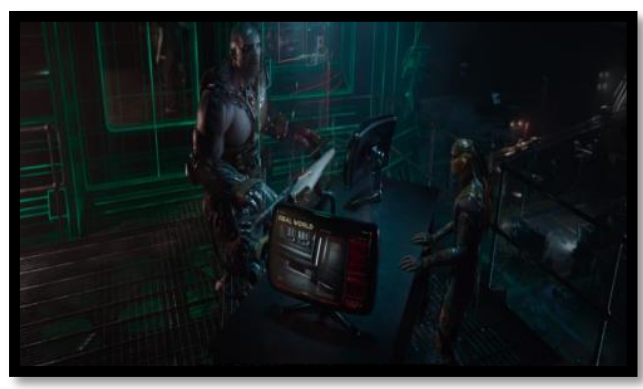

Kesit 16

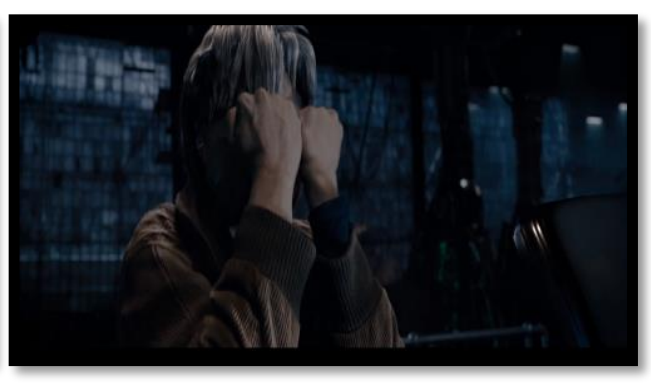

Kesit 15

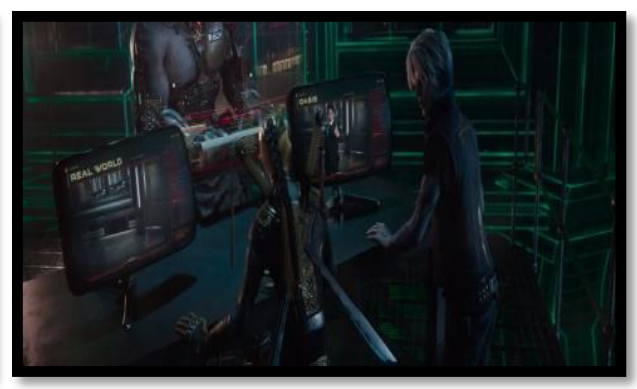

Kesit 17 
Kesit 14, Kesit 15, Kesit 16 ve Kesit 17 sanal ile gerçek olanın birbiri içerisinde geçmesini örneklendirmek açısından önemli rol oynamaktadır. Kesit 14'te, ilk bakışta gerçek dünyada Wade Watts ve arkadaşının, Nolan Sorrento'ya (oyun şirketinin yöneticisi) silah doğrultarak, Sorrento'nun alı koyduğu diğer arkadaşının yerini öğrenmek istediğini görmekteyiz. Bu sahnede Watts ve arkadaşı haricinde Sorrento gerçekte kendi ofisinde olduğunu zannetmektedir. Fakat filmin dakikası ilerlerken Watts'ın başka bir odaya geçmesi ve gerçek görüntüsünün altından (Kesit 15-bkz. bedensizleşme) avatarını çıkartması, akıllarda soru işareti bırakmaktadır. Bu esnada Watts'ın diğer arkadaşının, “OASIS'te olduğunu fark etmedi mi?” cümlesi üzerine yaşanan olayların sanal evrende gerçekleştiği anlaşılmaktadır. Çünkü daha sonra Kesit 16 ve Kesit 17'de Watts ve arkadaşları, Sorrento'nun oyun konsolunu nasıl hacklediklerini ve simüle ofis evrenini yaratıklarını açıklamaktadır. Ek olarak Kesit 17'de yer alan iki ekran görüntüsünün üzerinde gerçek dünya ve OASIS yazması iki farklı boyut evreninin bir arada kullanılmasına ve kimi zaman birbirinin yerine geçebilmesini anlatıııstır.

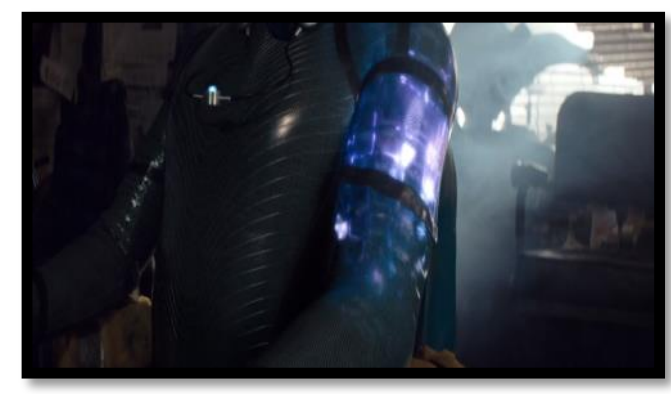

\section{Kesit 18}

Kesit 18, OASIS evrenine bağlanmak için dokunsal (kostüm) giyen Watts'ın kolunu göstermektedir. Kolunda mavi ışığın dolaşması Watts'ın o esnada sanal evrende vücudunda hissettiği hislerin gerçek hayatta da vücudunun aynı noktalarında hissedilebildiğinin sahnelenmesi yapılmıştır. Bu kare bedensizleşmeyi akıllara getirerek gerçek ve sanal dünya arasındaki hissiyat algısındaki ayrımın silikleştiğini göstermektedir. 


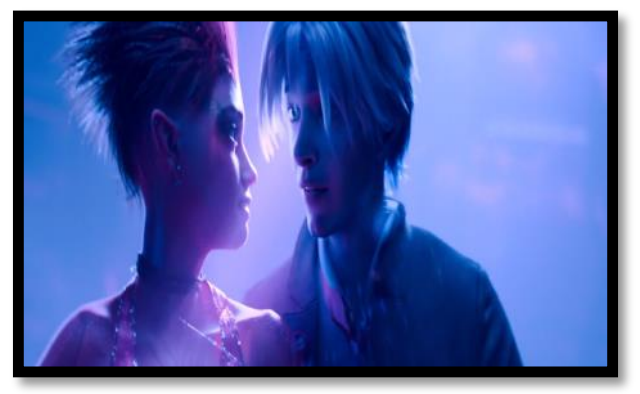

Kesit 19

Kesit 19'da Art3mis ve Parzival sanal evrende dans ederken sahnelenmiştir. Bu esnada aralarında geçen diyalog çalışma için önem teşkil etmektedir. Parzival Art3mis’e, “Gerçek dünyada da buluşsak çok güzel olur... senden hoşlanıyorum.” demiştir. Art3mis ise ona, "Beni tanımıyorsun bile, gerçekte böyle görünmüyorum (avatar), bu gerçek vücudum değil, gerçek yüzüm değil..." şeklinde yanıt vermiştir. Parzival ise onun (Art3mis) gerçekte ismini öğrenmeye çalışmaktadır. Konuşmalarının sırasında Parzival gerçek adını Art3mis'e söylediğinde Art3mis, "Delirdin mi sen? Kimseye kim olduğunu söyleyemezsin, gerçek adını kullanamazsın." demiştir. Parzival ve Art3mis arasında geçen bu diyaloglar bireylerin simülasyonda tanımadıkları sanal kişilere âşı olabileceklerini, sırlarını paylaşabileceklerini/paylaşamayacaklarını, kuralları çiğneyebileceklerini/çiğneyemeceklerini göstermektedir. Gerçek dünyada hiç tanımadığı ya da bilmediği kişilerle sanal evrende bağlantı kuran bireyler iyi-kötü, doğru-yanlış arasındaki ayrımı yapamaz konuma gelmektedir, bilgisi kesit 19'da örneklendirilmiştir.

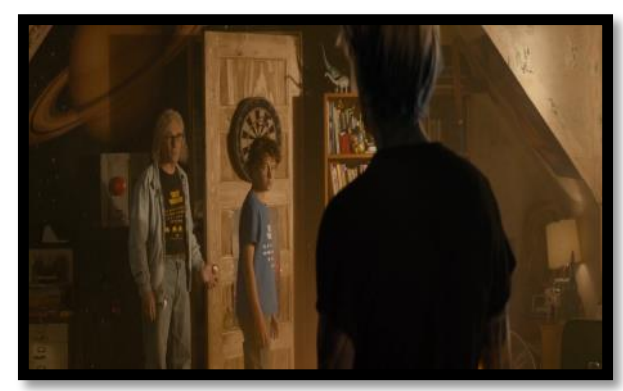

\section{Kesit 20}

Kesit 20, filmin son kareleri arasında yer almaktadır. Oyunu kazanan Wade Watts, OASIS'in kurucusu Halliday ile sanal evrende konuşmaktadır. Halliday'ın yanındaki küçük erkek çocuk onun (Halliday) çocukluğudur. Kesit 20'de hem bireyler üzerinden üç ayrı dönemin aynı zamanda eş kullanılmasıyla zaman parçalanması anlatılmış hem de avatarlar ile 
gerçek bireylerin karşılıklı konumlandırılması kadraja yansıtılmıştır. Söz konusu karede Watts, Halliday’e sorduğu “Avatar değilsiniz değil mi?” sorusuna karşılık hayır yanıtını almıştır. Watts, bunun üzerine “Halliday gerçekten öldü mü?” sorusunu sormuştur, Halliday bu soruya evet yanıtını vermiştir. Watts, “O zaman siz nesiniz?” soruna karşılık bulamamış ve filmin de kilit noktası burada tartışılmaya başlanmıştır. Bu tartışma beraberinde postmodern dönem içerisinde hipergerçekliğin yeni ve farklı bir dönemi işaret ettiğini akıllara getirmiştir. Gerçek yerini hipergerçeğe bırakırken, hipergerçek yerini neye ya da nelere bırakmaya başlamıştır sorusu, hipergerçekliğin katmanlı yapısının derinleşmeye başladığının işareti sayılmaktadır.

Tablo 1. Başlat: Ready Player One Filmi Görüntüsel Gösterge Anlam Tablosu

\begin{tabular}{|c|c|c|c|}
\hline \multicolumn{4}{|c|}{ Görüntüsel Gösterge } \\
\hline \multirow[t]{2}{*}{ Gösterenler } & \multirow{2}{*}{$\begin{array}{l}\text { Sekans } \\
\text { Sayısı }\end{array}$} & \multicolumn{2}{|c|}{ Gösterilenler } \\
\hline & & Düz Anlam & Yan Anlam \\
\hline Gerçek Dünya & 510 & $\begin{array}{l}\text { Yaşadığımız } \\
\text { Gezegen }\end{array}$ & $\begin{array}{l}\text { Yiğınlardan Oluşmuş } \\
\text { Postmodern Dünya }\end{array}$ \\
\hline Gerçek Birey & 452 & İnsan & $\begin{array}{l}\text { Teknolojinin Uzantıs1 } \\
\text { Hâline Gelmiş Birey }\end{array}$ \\
\hline Teknolojik Aletler & 165 & Teknolojik Alet & $\begin{array}{c}\text { Simülasyona Bağlanma } \\
\text { Aracı }\end{array}$ \\
\hline $\begin{array}{l}\text { Sanal } \\
\text { Evren }\end{array}$ & 757 & Sanal Evren & $\begin{array}{l}\text { Bireyin Özgür Tercih } \\
\text { Yapabildiği (-Miş)Evren }\end{array}$ \\
\hline Avatar & 745 & Avatar & $\begin{array}{l}\text { Simülasyondaki Birey } \\
\text { Görünümleri }\end{array}$ \\
\hline Anahtar & 21 & Eşya & $\begin{array}{l}\text { Arzu Nesnesine } \\
\text { Ulaşmanın Aracı }\end{array}$ \\
\hline
\end{tabular}

Tablo 1.'de Başlat: Ready Player One filminin Görüntüsel Gösterge Anlam Tablosu ele alınmıştır. Bu bağlamda filmin sahne yerine sekans sayıları sayılarak her bir karenin gösterdiği anlam ve bütünlüğüne bakılmıştır. Sahneler arası kesmelerin hızlı yapılması oluşturulan sahnenin sayılmasını zorlaştırmış ve dolayısıyla sekansın ele alınması uygun görülmüştür.

Film içerisinde gerçek dünya düz anlamında yaşadığımız gezegini betimlerken, yan anlamında ise modernden ziyade postmodern izler taşıdığı Kesit 1'de de ifade edilmiştir. Gerçek bireyler filmde postmodern dünyanın kaotik ortamında sıkışıp kalan insanları tanımlamaktadır. Yan anlamında ise yaşadığı yerden ve durumdan en önemlisi de kendisinden memnun olamayan postmodern insanının bir kaçış olarak teknolojik aletlerle bütünleşmesi 
anlatılmıştır. Film boyunca simülasyona bağlanma aracı işlevini gören teknolojik aletler; vizöreldiven ya da dokunsal kostümden oluşmaktadır. Sanal evren/OASIS yan anlamında bireylerin kendilerini yeni baştan revize ettikleri, özgür oldukları alan olarak görülmektedir. Bu konuda filmin başlarında Wade Watts'ın sanal dünyayı tanıtırken sarf ettiği sözler Kesit 2, Kesit 3 ve Kesit 4'te de açıklanmıştır. Bireyler, sanal evrene asla sahip olamadıkları ya da olamayacakları hayata ya da görünüme kavuşmak için bağlanmaktadır. Dolayısıyla teknolojinin bir uzantısı hâline gelen birey, sanal evrende daha çok vakit geçirmektedir. Sanal evrende vakit geçiren bireyler istedikleri görünüme, yaşa ya da cinsiyete sahip olmak için kendilerine avatar yaratmakta ve oyun içerisinde coin (oyun parası) toplayarak avatarlarını revize etmektedir.

Filmde son olarak ele alınan ve değerlendirilen anahtarların, arzu nesnesine ulaşmanın aracı olarak rol aldığı saptanmıştır. Filmde Halliday’in ölümünden sonra OASIS’te başlatılan oyunun son bulması için ulaşılması gerekilen yumurta ise arzu nesnesi olarak konumlandırılmıştır.

\section{SONUÇ}

Modernizmin eleştirdiği yapıları taklit etmeye başlaması ve savunduğu radikal kopuş ile ilerlemeciliği yerine getirememesi, özellikle postmodernistler tarafından eleştirilmiştir. Postmodernizm öncelikle sanat, edebiyat, mimari alanlarda ortaya çıkan bir akım olarak görülse de daha sonradan tüm toplum dinamikleri için kullanılmaya başlanmıştır. Literatürde tek bir tanımın bulunmadığı postmodernizm, günümüz toplumlarını konumlandırmak için kullanılmaya başlanmıştır. Bu bağlamda postmodernizm, modernizmin ilkelerini bir kenara bırakarak çoğulculuğu, farklılığı ve bireyin özgürleşmesini savunmaktadır. Ekonomik, siyasi ve sosyo-kültürel yapıda etkin olmaya başlayan postmodernizm, küresel düzende çeşitliliği meydana getirmiştir. Postfordizm ile üretim ve tüketim ilişkileri değişmiş, bu durum bireylerin gündelik yaşamlarını etkilemiştir. Postmodern dönem yarattığı değişikliklerle belirsizliklerin, kaosun, süreksizliğin ve zamanda belirsizliğin dönemi olarak yerini almıştır.

Postmodernizm çalışmalarında Jean Baudrillard önemli isimler arasında sayılmaktadır. Baudrillard'a göre de postmodern dönem anlamsızlıkların inşa edildiği süreci ifade etmektedir. $\mathrm{O}$, bu dönemin tüketimine ve gerçekliğine yaptığ 1 vurguyla postmodern dünya inşasına yeni bir perspektif kazandırmıştır. Postmodern dönemde gerçekliğin kalmadığına değinen Baudrillard, 
gerçekliğin yansımalardan oluştuğuna ve bu gerçekliğin de bir üst boyut olarak simülasyonla yani hipergerçelikle yaratıldığını belirtmektedir. Postmodern dönemi insanları da gerçek ve hipergerçek arasındaki ayrımı yapamamaya ve aynı zamanda iyi-kötü, doğru-yanlış algısını kaybetmeye başlamaktadır. Yaşadığımız dönem gerçekliğini hipergerçek olarak açıklamaya çalışan Baudrillard, gerçekliğin bilgisayar ortamı, matris ve benzerleriyle yeniden üretildiğini, şekillendirildiğini ve herkesin gerçekliğinin farklılaşmaya başladığına işaret etmektedir. Özellikle teknolojinin gelişmesiyle arttırılmış gerçeklik teknolojisinin ortaya çıkması ve hemen ardından sanal gerçeklik/VR teknolojisinin peşi sıra kullanıma sunulması Baudrillard'ın hipergerçek anlayışına grift bir yapı kazandırmıştır. Bu yüzden çalışma boyunca amaçlı örneklem olarak seçilmiş filmde postmodernizm, Baudrillard ve hipergerçek getirileri üzerinde odaklanılmıştır.

Film, sanal ve gerçek dünya ayrımında yaşayamayan bireyleri sorgulatırken, postmodern izler çizmektedir. Filmde gerçek hayat yığınlar adı verilen yerle ilişkilendirilmiştir. Burada insanlar üst üste eski banliyö tarzı evlerde yaşamaktadır. Kaosun ve karmaşanın hâkim olduğu yerde insanlar gündelik sorunlarını çözmek yerine bu sorunları kanıksamış, artık onlarla yaşamaya başlamıştır. Postmodern toplum izlerini taşıyan film döneminde bireyler, zorunlu ihtiyaçları haricinde yaşamsal vakitlerinin çoğunu OASIS adlı sanal evrende harcamaktadır. Bireyler, eldiven-vizör ya da dokunsal adı verilen kostümle simülasyona direkt bağlanarak avatarlarını aktif hâle getirmektedirler. Bu evrende istedikleri her yere gidebilme ve her şey olabilme özgürlüğüne kavuşan bireyler, gerçek hayatta bulunma oranını en aza indirgemeye başlamıştır. Kendisinden memnun olmayan özne olarak insan, sanal dünyanın simüle ettiği parçalanmış gerçekliğin yeni, hipergerçek boyutuyla tanışmaktadır. Bu evrende birey daha uzun boy, daha ince fizik, daha güzel, daha yakışıklı ve benzeri gibi niteliklere sahip olabilmektedir. Hatta bu evrende savaşa ya da çeşitli etkinliklere katılarak coin (oyun parası) biriktirmekte ve biriktirdiği coinlerle avatarını revize edebilme şansı da yakalamaktadır. Fakat girdiği savaş ya da etkinlikte kazandığı kadar kaybetme ihtimali de olan sanal evren bireyi, kayıpların sonucunda gerçek dünyada öfke patlamaları yaşamakta ve bununla da yetinmeyip intihar teşebbüsünde dâhi bulunabilmektedir (Bkz. Kesit 8). Sanal ve gerçek olanın ayrımının güçleştiği postmodern dönemde Baudrillard'ın da dediği gibi birey algısında, sanal ile gerçeğin ayrımını silikleşmektedir. Başka bir örnek daha verilecek olursa Kesit 6, Kesit 7, Kesit 8 ve 
Kesit 9'da gösterilen olaylar, sanal ile gerçek dünyanın ayrımının bilinemezliğine vurgu yapmaktadır.

Film içerisinde ele alınması gereken diğer önemli bir konu ise postmodern dönemde zamanın bilinemezliği, parçalanmışlığıdır. Kesit 12 ve Kesit 13 'te tam da bu durum anlatılmıştır. Kesit 12'de Parzival'ın, Halliday'ın anısına bağlanarak onu gözetlemesi, üstelik bunu OASIS evrenindeyken yapması hem gerçek ve sanal dünyanın iç içe geçmesine hem de zaman ve uzamın parçalanmışlığına örnek olarak verilebilir. Yine Kesit 13'te Parzival ve arkadaşlarının 1980 yapımı "The Shining” filminin içine düşmesi hipergerçek ile oluşturulan yeni gerçeğe, yeni uzam ve zamana, kısacası yeni bir boyuta işaret etmektedir. Kesit 20'de sanal evrende/OASIS'te Parzival, Halliday ve Halliday'in küçüklüğü bir arada gösterilmiştir. Üç ayrı zamanın, üç ayrı şekilde aynı anda verildiği söz konusu karede, zamanlar net olarak bilinmemekle beraber sanal ve gerçekliğin ayrımı yine bulunmamaktadır. Son olarak Kesit 20'de Halliday' in öldüğünün bilinmesi, fakat konuşan kişinin Halliday' in avatarı olmadığının anlaşılması, postmodern durumun ötesinde daha farklı bir dönemin başladığına işaret edildiği şeklinde yorumlanabilir.

Sonuç olarak film akışı minvalinde yer alan değerlendirmelerimiz neticesinde gerçek yerini hipergerçeğe bırakırken, hipergerçek yerini neye/nelere bırakmaktadır sorunsalıyla karşılaşmaktayız. Ayrıca bu durumun postmodern dönemin tekrardan sorgulanmasına neden olabileceği de yadsınmamaktadır. Teknolojik atılımlarla hipergerçek alanında her geçen gün sıçramalar yaşanması, hipergerçek ötesi dönemin düşünülmesini gerekli kılmaktadır. Çağın ihtiyacı olan revizelerle birlikte yapılacak olan araştırmalar bu konuda önemli görülebilir. Dolayısıyla modernizm eleştirisi ile başlayan postmodernizmin tam olarak tanımlanamamasına rağmen yakın geleceğimiz için teknolojide yaşanan hipergerçek-boyutlararası sıçramalarla beraber yeni bir dönemi beraberinde getirebileceğini akıllara getirmektedir.

\section{EXTENDED ABSTRACT}

Modernism is thought of as a period of new dynamics that occurred with the Renaissance, Reform and enlightenment. Modernism has adopted mold judgments and what is standard. It also provided no living space to different identities. Along with postmodernism, the qualities of modernism have been left behind. Postmodernism adopted variability and 
ambiguity. In postmodernism, the living space of different identities has proliferated. This is why the transition between identities has increased.

Since uncertainty prevails in postmodernism, there is no single reality. Jean Baudrillard is the name that comes up with his work at this point. Baudrillard specifically mentions hyperrealism in his work simulation and simulacr. A different reflection of reality, called simulation or hyperrealism is important for the perception of the postmodern era. Baudrillard states that today's reality is produced by matrices, memory, or miniaturized cells. This situation creates pluralistic virtual realities and prevents talking about a single reality. Therefore, the individual has started to become an extension of technology today. With the new world created, the individual set out to claim to be freer, but came under the domination of technological instruments. The Postmodern period, together with all these qualities, points to the Unreal.

This study, includes Baudrillard's views along with postmodernism. Baudrillard's aforementioned views are gradually gaining depth in today's postmodern world where technology is developing. Hyperreal has gained a new dimension with technological developments. This situation was tried to be explained in the sample of the movie "Start: Ready Player One" selected as a purposeful sample in the context of postmodern and hyperreality. As method, semiotic analysis was applied to the film in line with Roland Barthes ' views. In this axis, the description of the postmodern world and the evaluation of the hyperreality dimension were made especially in the cross-sectional analysis. Semiotics is approached in many ways. But in the context of the issue, Barthes ' views will be focused on. Barthes approached semiotics with the dimensions revealed by many language schools. Therefore, Barthes gave an interdisciplinary nature to semiotics. In semiotics, Barthes opened the door to a new dimension of interpretation, together with the structures of metaphor and methanomy.

While the film makes us question the individuals who cannot live between virtual and real world, it draw postmodern marks. Therefore, in the analysis and findings section of the study, cross-sectional analysis and visual indicator meaning table were prepared. In the prepared tables and cross-sections, inferences were made and interpreted based on Baudrillard's views. In the movie, it was shown that the individual's life in the real world is chaotic. Individuals fleeing their real-life responsibilities seek refuge in the virtual world. Individuals fleeing all this chaos find themselves in a virtual world called OASIS. In OASIS, while individuals have the identities they want, they move away from reality. Individuals have the 
chance to make themselves look more beautiful, handsome, thinner or smarter in OASIS. In the film, real individuals are shown as people trapped in the chaotic environment of the postmodern world. Metaphorically, the integration of postmodern people who are dissatisfied with themselves with technological tools is explained. Thus, the individual, which is the extension of the technology, is depicted with the postmodern narrative in the created world. Another important issue to be addressed in the film is the uncertainty and fragmentation of time in the postmodern period. The intertwining of the real and virtual world in the film is an example of the fragmentation of time and space. Therefore, it can be explained by hyperrealistic leaps dimensions that the postmodern, which takes place differently from modernism, can go further.

As a result, the concepts Baudrillard brought to the literature and the relation between postmodernism was made through sampling the selected movie. It has become difficult to live in uncertain, irregular, chaotic and different situations brought about by the postmodern. This situation, as can be seen in the analysis and findings section of the study, is shown throughout the film as the subject's escape from the real-world existence of the individual. The individual felt safer and happier in the virtual world and started to move away from real life. The tools used to connect to the virtual world with the effect of technological progress create the feeling of reality that is fake in individuals. Individuals who are pursuing fake feelings become more dependent on the virtual world and, as Baudrillard says, begin to be deprived of reality. Therefore, individuals cannot make the distinction between fake and real. In a world where individual freedom cannot be achieved, it must be questioned with hyperreal leaps beyond postmodern.

\section{KAYNAKÇA}

Barthes, R. (1979). Göstergebilimin ilkeleri. (B. Vardar, \& M. Rıfat, Çev.) Ankara: Kültür Bakanlığı Yayınları.

Baudrillard, J. (2010). Sessiz yığınların gölgesinde-Toplumsalın sonu. (O. Adanır, Çev.) Ankara: Doğu Batı Yayınları.

Baudrillard, J. (2011). Simülakr ve simülasyon. (O. Adanır, Çev.) Ankara: Doğubatı Yayınları.

Bell, D. (1976). The cultural contradictions of capitalism. New York: Basic Books. 
Berman, M. (2006). Katı olan herşey buharlaşıyor. (Ü. Altuğ, \& B. Peker, Çev.) İstanbul: İletişim Yayınları.

Berryman, D. R. (2012). Augmented reality: A review. Medical Reference Services Quarterly, 31(2), 212-218.

Best, S., \& Douglas, K. (2016). Postmodern teori. (M. Küçük, Çev.) İstanbul: Ayrıntı Yayınları.

Cevizci, A. (2000). Felsefe sözlüğ̈̈. İstanbul: Paradigma Yayınları.

Cevizci, A. (2002). Aydınlanma felsefesi tarihi. Bursa: Ezgi Kitabevi.

Cevizci, A. (2009). Felsefe tarihi. İstanbul : Say Yayınları.

Daşkıran, L. (2016). Sanal gerçeklik çağına hazır mısınız? Bilim ve Teknik, 66-73.

Demir, Y. (2001). Modernizmden postmodernimze geçiş süresinin dinamikleri. Yayımlanmamış Yüksek Lisans Tezi. Sakarya: Sakarya Üniversitesi Sosyal Bilimler Enstitüsü.

Eagleton, T. (1999). Postmodernizmin yanılsamaları. (M. Küçük , Çev.) İstanbul: Ayrınt1 Yayınları.

Gasset, O. (2010). Kitlelerin ayaklanması. (N. G. Iş1k, Çev.) İstanbul: Türkiye İş Bankası Kültür Yayınları.

Güzel, M. (2014). Postmodern dönemde epistemolojik hakikat sorunu: Baudrillard örneği. Yayımlanmamış Yüksek Lisans Tezi. Bursa: Uludağ Üniversitesi Sosyal Bilimler Enstitüsü.

Harvey , D. (2010). Postmodernliğin durumu. (S. Savran, Çev.) İstanbul: Metis Yayıncılık.

Hoffman, H. G., Hullfish, K. C., \& Houston, S. J. (1995). Virtual-reality monitoring. Virtual Reality Annual International Symposium (s. 48-54). Research Triangle Park,North Carolina: IEEE Computer Society Press.

Huyssen, A. (2011). Postmodernitenin haritasını yapmak. M. Küçük içinde, Modernite versus postmodernite (s. 231-262). İstanbul : Say Yayınlar1 .

Jeanniere, A. (2011). Modernite nedir? M. Küçük içinde, Modernite versus postmodernite (N. Tutal Küçük, Çev., s. 111-124). Ankara: Say Yayınları.

Kant, I. (2005). Aydınlanma nedir? Liberal Düşünce, 10(38-39), 225-230.

Karasar, N. (2018). Bilimsel araştırma yöntemi. Ankara: Nobel Yayıncılık.

Kumar, K. (2013). Sanayi sonrası toplumdan postmodern topluma; çağdaş dünyanın yeni kuramları. (M. Küçük, Çev.) Ankara: Dost Kitabevi.

Meijsing, M. (2006). Real people and virtual bodies: How disembodied can embodiment be? Minds and Machines, 16(4), 443 - 461. 
Mutlu, E. (2012). İletişim sözlüğü. Ankara: Sofos Yayınları.

Saklı, A. R. (2007). Kapitalist gelişim sürecinde fordizm ve post-fordizm. Elektronik Sosyal Bilimler Dergisi, 12(44), 107-131.

Sarup, M. (2010). Post-yapısalcılık ve postmodernizm. (A. Güçlü, Çev.) İstanbul: Kırk Gece Yayınları.

Soykan, Ö. N. (1993). Türkiye'de felsefe manzaraları. İstanbul: Yap1 Kredi Yayınları .

TDK. (tarih yok). Türk Dil Kurumu Sözlükleri. 10 15, 2020 tarihinde Türk Dil Kurumu Web Sitesi: https://sozluk.gov.tr/ adresinden alınd1

Turner, G. (2016). Ingiliz kültürel çalışmaları. (B. Özçetin, \& D. Özçetin, Çev.) Ankara: Heretik Yayınları.

Tüzen, H. (2008). Postmodernizmin mitosu. Süleyman Demirel Üniversitesi Fen-Edebiyat Fakültesi Sosyal Bilimler Dergisi, 145-158.

Urry, J. (1999). Mekânları tüketmek. (R. G. Öğdül, Çev.) İstanbul: Ayrıntı Yayınları. 